\title{
Antibacterial and Antioxidant Activities of Different Varieties of Locally Produced Egyptian Honey
}

\author{
Aliaa M. El-Borai ${ }^{1 \#}$, Ghada A. Youssef ${ }^{1}$, Doaa A. Ghareeb ${ }^{2,3}$ and Mai M. Abdel-Tawab ${ }^{1}$ \\ ${ }^{1}$ Botany \& Microbiology Department, Faculty of Science, Alexandria University, \\ Alexandria, Egypt; ${ }^{2}$ Biological Sciences Department, Faculty of Science, Beirut Arab \\ University, Beirut and ${ }^{3}$ Biochemistry Department, Faculty of Science, Alexandria \\ University, Alexandria, Egypt.
}

$\mathbf{T}$

HE PRESENT study investigated the physicochemical, antioxidant, and microbiological properties of six types of honey obtained from Alexandria, Egypt. Physicochemical properties showed that optical density in the tested honey samples ranged from 0.50 to 1.65 , while the $\mathrm{pH}$ was in the acidic range. Moisture contents and electrical conductivity in honey samples ranged from 0.5 to 0.64 , and $0.29-0.79 \mathrm{mScm}^{-1}$, respectively. Total phenol varied from 5500 and $14120 \mathrm{mg} / \mathrm{kg}$ in the samples. Flavonoid contents were between $926-1657 \mathrm{mg} / \mathrm{kg}$. The greater amount of phenolic and flavonoid compounds leads to more potent radical scavenging effect as shown by Cotton, Eucalyptus, and Black seed honey samples. Microbiological characteristics showed that Black seed followed by Eucalyptus honey extracts gave the maximum antibacterial activity against $K$. pneumonia, P. aeruginosa, P. mirabilis, E. coli and S. mutans with maximum inhibition zones equal to $42.67,39.00,36.00,27.33$ and $18.67 \mathrm{~mm}$ at $100 \mu 1$, respectively, for Black seed honey, and 41, 38.33 and $35.67 \mathrm{~mm}$ and approximately equal inhibition zones of $13.67 \mathrm{~mm}$ against $E$. coli and $S$. mutans at $100 \mu \mathrm{l}$, respectively, for Eucalyptus honey. The minimum inhibitory concentration values against the pathogenic bacteria showed that, at $25 \%$ concentration, Black seed and Eucalyptus honey had an effect on E. coli and K. pneumonia, while Clover honey had an effect on P. aeruginosa and P. mirabilis. Thus, honey can be used for nutritional, medicinal and industrial purposes and can be an important commodity in the international market.

Keywords :Antibacterial, Antioxidant, Local natural honey, Pathogenic bacteria, Egyptian Honey

\section{Introduction}

Honey is a natural sweetener, which is widely available across the world. It is extensively used among various natural products, for various applications, some are clinical and contains approximately 200 distinct chemical compounds. Several research studies have studied many of its biological properties, such as antioxidant, antiinflammatory, anti-bacterial, antiviral, anti-ulcer activities; and antihyperlipidemic, antidiabetic and anticancer properties (Rao et al., 2016).

It is a supersaturated solution of sugars, composed of mainly fructose and glucose, and many other minor components such as minerals, proteins, free amino acids, vitamins, enzymesglucose-oxidase, and catalase-, phenolic acids, and flavonoids honey's composition is variable and its properties vary greatly depending on floral source, climate, and environmental and processing conditions (Ramos et al., 2018)

The possible health benefits of consuming honey have been subjected to extensive study all over the world on its ingredients, physicochemical properties, vitamins, mineral content and quality control (Chen et al., 2012).

Numerous studies have reported that most chronic diseases such as cancer, coronary, and neurological degeneration are a consequence of oxidative damage. It is also proven that the therapeutic potential of honey is always associated with antioxidant capacity against reactive oxygen species (Ferreira et al., 2009). Components in honey reported to be responsible for its antioxidant effects are flavonoids, phenolic acids, ascorbic acid, 
catalase, peroxidase, carotenoids, and the products of Maillard reactions (Mohammed et al., 2014).

Polyphenols are currently of particular interest, mainly because of their functional properties. Besides being radical scavenger, polyphenol could be an effective immune modulator and hormone action inhibitor. Polyphenols are believed to be potent scavengers of peroxyl radicals, mainly because of the presence of high mobility of hydrogens in their molecular structures. Of the polyphenols, phenolic acids are likely to be the major group in honey. They affect the flavor and physical appearance of honey, particularly honey color. Interestingly, they have been given considerable attention to be an eligible parameter for honey quality assessment, as well as for honey marker identification, with the help of the advancement of liquid chromatography and mass spectrometry technology nowadays (Chua et al., 2013).

Antimicrobial activity of honey is due to peroxide and non-peroxide factors. As to the first ones, some investigators have estimated that the major one is hydrogen peroxide, resulting of the oxidation of glucose by glucose oxidase during the ripening of honey. While, the nonperoxide is due to antimicrobial factors, physicochemical characteristics-high osmolarity, acidity, peptides, lysozyme, phenolic acids, and flavonoids (Ramos et al., 2018).

In the present study, antibacterial activities of six different Egyptian honeys collected and tested against six pathogenic bacteria in different conditions. Physical, chemical and antioxidant properties of local honeys were also studied to investigate and evaluate of functional properties of local to confirm its economical and nutritional importance.

\section{Materials and Methods}

\section{Bacterial strains and cultivation}

Six pathogenic bacterial species including Gram-positive and Gram-negative were used. These bacteria were kindly provided from The National Institute of Oceanography and Fisheries, and The High Institute of Public Health, Egypt. The Gram-negative bacteria were E. coli, P. mirabilis, $K$. pneumoniae, and $P$. aeruginosa, while the Gram-positive bacteria were Staph. aureus, and $S$. mutans.
Prior to the experiment, the strains were inoculated onto the surface of nutrient agar media; the inoculums suspensions were obtained by taking five colonies from $24 \mathrm{~h}$ cultures. The colonies were suspended in $5 \mathrm{ml}$ of sterile saline $(0.85 \% \mathrm{NaCl})$ and shaken for $15 \mathrm{sec}$. The density was adjusted to the turbidity of a $0.5 \mathrm{McF}$ arland Standard (equivalent to $1-5 \times 10^{8} \mathrm{cfu} / \mathrm{ml}$ ).

\section{Honey samples}

Six locally produced honey samples were purchased from Al-Dakhakhny Honey Market in Alexandria, Egypt. These samples were Cotton, Citrus, Sidr, Black seed, Eucalyptus, and Clover honey.

\section{Physicochemical honey properties}

The optical density of honey was determined by dissolving one gram of honey with $9 \mathrm{ml}$ of distilled water and centrifuging for $10 \mathrm{~min}$ at 3000 $\mathrm{rpm}$. The absorbance of the filtrate supernatant at $530 \mathrm{~nm}$ against distilled water as a blank using a computerized UV-Visible Spectrophotometer (T70 Split-Beam UV/VIS Spectrophotometer, England). The $\mathrm{pH}$ of honey filtrate was determined by $\mathrm{pH}$ meter as previously described (Egan et al., 1987). The water content of honey was estimated using an Abbe refractometer $(A=589 \mathrm{~nm})$, that measures the refractive index of samples according to the method previously recommended (William, 1980). The electrical conductivity was estimated using conductometer (WTW. D8120 Weilheim LF. 42) from a solution containing 10 $\mathrm{g}$ of honey in $75 \mathrm{ml}$ of distilled water. The result is expressed in milliSiemens per centimeter $(\mathrm{mS}$. $\mathrm{cm}^{-1}$ ) (Vorwohl, 1964).

\section{Antioxidant activity \\ Total phenolic content}

Phenolic compounds were determined according to Singleton et al. (1999), using FolinCiocalteu reagent and saturated sodium carbonate solution $(75 \mathrm{~g} / \mathrm{L})$. The tubes were left in the dark at room temperature for two hours for color development, and then absorbance was read at $765 \mathrm{~nm}$ by a spectrophotometer. A calibration curve was made by using a solution of gallic acid.

\section{Total flavonoid content}

Honey solution (100 mg ml) was prepared with methanol $50 \%$ and previously homogenized and filtered through quantitative filter, $5 \mathrm{ml}$ of honey solution was mixed with $5 \mathrm{ml}$ of $\mathrm{AlCl}_{3}$ $(2 \%)$ in methanol. The mixture was homogenized 
and allowed to stand for $30 \mathrm{~min}$. The absorbance was measured at $415 \mathrm{~nm}$. Quercetin was chosen as a standard, using a seven point standard curve $(0-50 \mathrm{mg} / \mathrm{L})$, the data were expressed as milligram quercetin equivalents $(\mathrm{QE}) / \mathrm{g}$ lyophilized powder (Chang et al., 2002).

Determination of DPPH (2, 2-Diphenyl-1picryl hydrazyl) scavenging activity

The DPPH assay was done as described by Koleva et al. (2002). Different concentrations of each honey sample or quercetin (test or standard, respectively) were added, at an equal volume, to methanolic solution of DPPH $(100 \mathrm{uM})$. The positive control was a mixture of equal volumes of methanol and DPPH solution while the blank was methanol alone. After $15 \mathrm{~min}$ at room temperature, the absorbance was recorded at $517 \mathrm{~nm}$. The $\mathrm{IC}_{50}$ values denote the concentration of sample, which is required to scavenge $50 \%$ of DPPH free radicals.

Determination of nitric oxide (NO) radical scavenging activity

Different concentrations of honey samples $(50 \mathrm{uL})$ were mixed with equal volume of sodium nitroprusside $(10 \mathrm{mM})$ in phosphate buffer saline for $150 \mathrm{~min}$ at room temperature using methanol as a blank. After incubation, $125 \mathrm{uL}$ of Griess reagent was added to each tube and incubated for another $30 \mathrm{~min}$. The absorbance of chromophore formed was measured at $546 \mathrm{~nm}$ on UV-visible spectrometer. Ascorbic acid was used as positive control. Scavenging/Reduction $\%=$ [Absorbance of control - Absorbance of test sample/Absorbance of control] X 100. The $\mathrm{IC}_{50}$ values for each test compounds as well as standard preparation were calculated (Natalia et al., 2014).

Determination of ferric reducing antioxidant power (FRAP) assay

One $\mathrm{ml}$ of honey of different concentrations was mixed with the same volume of sodium phosphate buffer and potassium ferricyanide in separate test tubes. The reaction mixtures were incubated in a temperature-controlled water bath at $100^{\circ} \mathrm{C}$ for $20 \mathrm{~min}$ followed by addition of $1 \mathrm{ml}$ of trichloroacetic acid. The mixtures were then centrifuged for $10 \mathrm{~min}$ at room temperature. The supernatant obtained $(1 \mathrm{ml})$ was added with $1 \mathrm{ml}$ of deionized water and $200 \mu \mathrm{L}$ of $\mathrm{FeCl}_{3}$. The blank was prepared as the samples except that potassium ferricyanide was replaced by distilled water. The absorbance of the reaction mixture was measured at $700 \mathrm{~nm} . \mathrm{IC}_{50}$ values denote the concentration of sample, which is required to scavenge/reduction $50 \%$ of FRAP free radicals (Sutharsingh et al., 2011).

\section{Screening of antibacterial activity}

The six types of honey were tested for antibacterial activity by well diffusion method and minimum inhibitory concentration (MIC) against pathogenic strains.

\section{Agar well-diffusion method}

Bacterial isolates were prepared to match 0.5 McFarland standards using the micropipette, 100 $\mu \mathrm{L}$ of organisms. Muller Hinton Agar plates were swabbed with $100 \mu \mathrm{L}$ of each strain of pathogenic organisms. Approximately 5-mm diameters of wells were punched in solid agar with a cork borer. Using a micropipette, different types of honey (5 $\mathrm{mg} / \mathrm{ml}$ ) were loaded at different concentrations including $25,50,75$ and $100 \mu \mathrm{L}$, then the plates were incubated at $37^{\circ} \mathrm{C}$ for $24 \mathrm{~h}$. Antibacterial activity was expressed as the diameter of the clear zone inhibition, measured in millimeters $(\mathrm{mm})$ (Mehrotra et al., 2010).

\section{Minimum inhibitory concentration (MIC)}

The MIC of the honey was determined using the serial micro dilution method as described by Samie et al. (2005). Control wells contained broth only (negative or sterility control) or bacteria and broth (positive control). One hundred microliter of the nutrient broth was added into each well of micro titration plate except row one of the positive control. Then, $100 \mu \mathrm{L}$ of the honey was then added into each well of micro titration plate except row one of the negative control. A twofold serial dilution was done by mixing the contents in each well of the first row and transferring $100 \mu \mathrm{L}$ to the second well of the same column and the same was done up to the last well of the same column and the last $100 \mu \mathrm{L}$ from the last well was discarded; $50 \mu \mathrm{L}$ of an overnight culture of the strain was mixed with the prepared extract dilutions and were incubated at $37^{\circ} \mathrm{C}$ for $24 \mathrm{~h}$. Data were analyzed according to Patton et al. (2006). Briefly, the optical density was determined just prior to incubation $\left(\mathrm{T}_{0}\right)$ and again after $24 \mathrm{~h}$ incubation $\left(\mathrm{T}_{24}\right)$ at $600 \mathrm{~nm}$ by IgGELISA Kit of Bioactivia-Germany. The OD for each replicate at $T_{0}$ was subtracted from the OD for each replicate at $\mathrm{T}_{24}$. The adjusted OD of each control well was then assigned a value of $100 \%$ growth. The percent inhibition of growth was thus determined using the formula Percent Inhibition $=1-(\mathrm{OD}$ test well/OD of corresponding control 
well) $\times 100$. The MIC is reported as the lowest concentration of test material which results in $100 \%$ inhibition of growth of the test organism. The MICs were tested for their antibacterial activity against the pathogenic bacteria which were E. coli, Proteus mirabilis, K. pneumoniae, $P$. aeruginosa, Staph. aureus, and S. mutans.

\section{$\underline{\text { Results and Discussion }}$}

\section{Physiochemical characteristics of honey}

The physicochemical properties of the different samples of local honey are reported in Table 1. The tested honey showed no sign of fermentation before initiating the physiochemical analysis. Physicochemical study showed that all the honey types were different in properties except that all were acidic. The color of honey types varies from golden yellow to dark brown, which is due to the presence of some different chemical constituents as reported by Taormina et al. (2001). The optical density in tested honey samples ranged from 0.50 to 1.65 . While the $\mathrm{pH}$ was in the acidic range and approximately equal in all honey types. These results are in agreement with Salonen et al. (2017) who mentioned that honey is acidic, and its $\mathrm{pH}$ ranges between 3.5 and 5.2. The $\mathrm{pH}$ of honey is low enough to inhibit the growth of many bacterial species, but this acidity may be neutralized in the body by the buffering liquid fluids. Radwan et al. (1984) reported that the acidity of honey is primarily to the content of gluconolactone/gluconic acid present as a result of enzyme action in the ripening nectar.

TABLE 1. Physicochemical properties of different varieties of honey

\begin{tabular}{lccccc}
\hline Honey type & Color & Optical density & $\mathbf{p H}$ & $\begin{array}{c}\text { Water } \\
\text { activity } \\
\left(\mathbf{a}_{\mathbf{w}}\right)\end{array}$ & $\begin{array}{c}\text { Electrical } \\
\text { conductivity } \\
\left(\mathbf{m S c m}^{-1}\right)\end{array}$ \\
\hline Cotton & Brown & 0.63 & 4.74 & 0.52 & 0.70 \\
Orange & Golden yellow & 0.50 & 4.17 & 0.5 & 0.34 \\
Sidr & Brown & 1.65 & 4.95 & 0.64 & 0.51 \\
Black seed & Brown & 0.59 & 4.52 & 0.5 & 0.88 \\
Eucalyptus & Dark brown & 1.05 & 4.20 & 0.52 & 0.91 \\
Clover & Golden yellow & 0.54 & 4.43 & 0.61 & 0.29 \\
\hline
\end{tabular}

The moisture contents in tested honey samples ranged from 0.5 to 0.64 , which are very similar to some studies which reported the moisture content of honey between 0.56 and 0.58 (Ruagg \& Blanc, 1981). The highest moisture content was found in Sidr honey. Moisture content variation can be explained by the composition and floral origin of honey samples. The low moisture content of honey forms an important part of the system which protects honey from attack by microorganism and therefore affects its storage life (Adenekan et al., 2010). Honey is a sugar solution of high osmolarity which inhibits bacteria. The high sugar concentration tie-up water molecules, so that bacteria would have insufficient water to support their growth (Malika et al., 2005).

The electrical conductivity (EC) values varied from $0.29-0.79 \mathrm{mScm}^{-1}$. The lowest was obtained from Clover honey samples and this was significantly different from the highest value of EC obtained from Eucalyptus. The EC is a good criterion related to botanical origin of honey and this is very often used in routine honey control instead of the ash content. The electrical conductivity may also be explained by taking into account the ash and acid content of honey, which reflects the presence of ions and organic acid; the higher their content, the higher the resulting conductivity (Adenekan et al., 2010).

\section{Antioxidant activity of honey}

Total phenolic and total flavonoid content

The phenolic contents of the honey samples were between 5500 and $14120 \mathrm{mg} / \mathrm{kg}$. The total phenolic content in Cotton honey $(14120 \mathrm{mg} /$ $\mathrm{kg})$ and Eucalyptus honey $(13690 \mathrm{mg} / \mathrm{kg}$ ) were the maximum. While low values were reported by Sidr and Orange honey samples. Honey samples from Brazil ranged from 870.83-1110.37 $\mathrm{mg} / \mathrm{kg}$ (Bueno-Costa et al., 2016). The results were higher than the commercial Slovenian 
honey which ranged from 44.8 to $233.9 \mathrm{mg} \mathrm{kg}^{-1}$ (Bertoncelj et al., 2007).

Flavonoids are low molecular weight phenolic compounds responsible for the aroma and the antioxidant potential of honey. Total flavonoid content among honey samples ranged between
926-1657 mg/kg (Table 2), and the maximum total flavonoid content was reported by Cotton (1657 $\mathrm{mg} / \mathrm{kg}$ ) followed by Eucalyptus (1415 mg/kg). The results are in agreement with those of several previous studies, in which it was found that honey samples with higher polyphenol content will also yield high flavonoid levels (Mohammed et al., 2014).

TABLE 2. Total phenolic and total flavonoid content of different varieties of honey

\begin{tabular}{lcc}
\hline Honey type & $\begin{array}{c}\text { Total Phenolic content } \\
(\mathbf{m g} / \mathbf{k g})\end{array}$ & $\begin{array}{c}\text { Total } \\
\text { Flavonoid content } \\
(\mathbf{m g} / \mathbf{k g})\end{array}$ \\
\hline Cotton & 14120 & 1657 \\
Orange & 5500 & 926 \\
Sidr & 6460 & 1119 \\
Black seed & 11150 & 1383 \\
Eucalyptus & 13690 & 1415 \\
Clover & 9520 & 126 \\
\hline
\end{tabular}

The total flavonone and dihydroflavonol content ranged from 1706 to $2606 \mathrm{mg}$ of pinocembrin $\mathrm{kg}^{-1}$ in the Brazilian honey as investigated by Pontis et al. (2014). The flavonoid content results in this study were higher than the results obtained for honey from the northeast of Brazil, which ranged from 2.5 to $83.8 \mathrm{mg}$ of quercetin $\mathrm{kg}^{-1}$ of honey (Liberato et al., 2011). Also, Meda et al. (2005) evaluated twenty-seven Burkina Faso honey samples and determined their flavonoid content using the aluminum chloride method, and their results ranged from 17 to 83.5 $\mathrm{mg}$ of quercetin $\mathrm{kg}^{-1}$ of honey.

The distinctive differences between different types of honey from different countries are caused by different locations, especially the climatic and vegetation conditions, and the flowering period of nectariferous plants (Lachman et al., 2010)

\section{DPPH scavenging activity test}

Table 3 shows the scavenging ability of honey samples expressed as $\mathrm{IC}_{50}$ with respect to the $\mathrm{DPPH}^{\circ}$ radical, which ranged from 24.07 to 95.07 $\mathrm{mg} / \mathrm{ml}$. Cotton honey had the highest antioxidant capacity $(24.07 \mathrm{mg} / \mathrm{ml})$. Possibly, observed high radical scavenging activity of the Cotton honey is due to the high phenolic and flavonoid contents in it, thus indicating high antioxidant potential.

Honey from the northeast of Brazil had $\mathrm{IC}_{50}$ values ranging from 4.2 to $106.72 \mathrm{mg} /$ $\mathrm{ml}$ although most values were above $20 \mathrm{mg} / \mathrm{ml}$ (Liberato et al., 2011). These results showed that the honey samples collected in the present study have greater antioxidant potential compared to the results reported in the other literatures. Furthermore, it was observed that the highest radical scavenging activity is linked with the highest honey concentration tested of all honey samples. Recently, similar findings were reported by Khalil et al. (2010) who found the highest scavenging activity at highest honey concentrations.

Nitric oxide (NO) scavenging activity test

Results in Table 3 shows the scavenging ability of honey samples expressed as $\mathrm{IC}_{50}$ with respect to the NO, which ranged from 5.52-83.07 $\mathrm{mg} / \mathrm{ml}$, with maximum NO scavenging activity reported by Cotton honey $(5.52 \mathrm{mg} / \mathrm{ml})$ followed by Eucalyptus and Black seed.

As free radical scavenger, it could be attributed to presence of conjugated ring structures and carboxylic group which have been reported to inhibit lipid peroxidation (Rice-Evans et al., 1995). NO is a free radical generated from sodium nitroprusside in aqueous solution at physiological $\mathrm{pH}$ and reacts with oxygen to form nitrite. It is well known that NO play an important role in various inflammatory processes such as carcinomas, juvenile diabetes, arthritis, multiple sclerosis and ulcerative colitis (Hazra et al., 2008). Lower values of NO radical scavenging activity expressed as $\mathrm{IC}_{50}$, represents high antioxidant activity as investigated by Jain \& Agrawal (2008). 
TABLE 3. Antioxidant activities of different varieties of honey

\begin{tabular}{lccc}
\hline Honey type & & IC $_{\mathbf{5 0}}(\mathbf{m g} / \mathbf{m l})$ & \\
& DPPH & NO & FRAP \\
\hline Cotton & 24.07 & 5.52 & $1.24 *\left(10^{3}\right)$ \\
Orange & 95.07 & 83.07 & $9.72 *\left(10^{3}\right)$ \\
Sidr & 57.4 & 51.34 & $4.85 *\left(10^{3}\right)$ \\
Black seed & 37.03 & 20.06 & $3.13^{*}\left(10^{3}\right)$ \\
Eucalyptus & 37.62 & 19.46 & $2.67 *\left(10^{3}\right)$ \\
Clover & 39.44 & 48.81 & $4.77 *\left(10^{3}\right)$ \\
\hline
\end{tabular}

Ferric reducing antioxidant power (FRAP) assay test

Higher FRAP values give higher antioxidant capacity where it directly estimates the presence of either antioxidants or reductants, depending on the ability of the analyte to reduce the $\mathrm{Fe}^{3+}$ / $\mathrm{Fe}^{2+}$ redox couple (Rabeta \& Nur Faraniza, 2013). In this study, values of FRAP were expressed as $\mathrm{IC}_{50}$ parameter. The FRAP values for the investigated honey samples ranged from $1.24 *\left(10^{3}\right)-9.72 *\left(10^{3}\right)$ as reported in Table 3. Significant differences among the FRAP values for the different types of honey, suggesting that they have different antioxidant potentials.

Cotton and Eucalyptus honey gave the highest values than others. The mean FRAP value of the investigated honey samples from Egypt is higher than that of Bangladesh honey (Mohammed et al., 2014), suggesting the high quality of Egyptian honey, as represented by their high antioxidant potentials.

\section{Antibacterial activity test \\ Agar well-diffusion method}

Antibacterial potency of honeys was investigated against various Gram negative and Gram positive pathogenic bacteria. All the honey types showed high antibacterial activity against most of the tested bacterial strains at $100 \mu \mathrm{l}$ concentration as shown in Fig. 1-6. K. pneumonia, P. aeruginosa, $P$. mirabilis, E. coli and $S$. mutans showed the maximum sensitivity to Black seed honey extracts with maximum inhibition zones equal to $42.67 \mathrm{~mm}, 39.00,36.00,27.33$ and 18.67 at $100 \mu \mathrm{l}$, respectively (Fig. 4). This was followed by extracts of Eucalyptus honey against $K$. pneumonia, $P$. aeruginosa and $P$. mirabilis which gave inhibition zones equal to 41, 38.33 and 35.67 $\mathrm{mm}$ at $100 \mu \mathrm{l}$ respectively and approximately equal inhibition zones equal to $13.67 \mathrm{~mm}$ against both E. coli and S. mutans (Fig. 5). In addition,
Clover honey extracts showed antibacterial effect against $K$. pneumonia, $P$. aeruginosa, $P$. mirabilis, $E$. coli and $S$. mutans by inhibition zones equal to $39.33,31.00,31.00,30.67$ and $25 \mathrm{~mm}$ at $100 \mu \mathrm{l}$ respectively (Fig. 6). The Orange, Sidr, and Cotton honey extracts recorded the lowest antibacterial effect among the six types. Orange honey had shown antibacterial effect against only $K$. pneumonia, $P$. mirabilis and $E$. coli giving inhibition zones equal to $36.33,34.33$ and $27 \mathrm{~mm}$ at $100 \mu \mathrm{l}$ respectively (Fig. 2). Results revealed a higher inhibition zone value for Gram negative bacteria comparing to the other tested Gram positive. This may be due to the differences in bacterial cell walls, since Gram negative bacteria have thinner cell wall comparing to Gram positive one (Rai et al., 2009).

The conflict in the observed antibacterial activity can be due to several reasons. It might be related to the differences in susceptibility of each species of microorganism to the antibacterial activity of honey used (Taormina et al., 2001). Moreover, it could also possibly be due to the different floral sources utilized by the bees and the geographical factors like temperature, humidity where the honey was produced and harvested. Some studies claimed that the antibacterial activity of honey is related to its acidity and other physiochemical parameters. Other possible explanation is the utilization of hydrogen peroxide and non-peroxide antioxidant components as reported by Melissa et al. (2004).

The differences in results may be also due to attributable to the method by which activity was assessed and variations in protocols between different research groups. In particular, the method for inoculating the agar, whether it is surface inoculation such as was used in the current study or incorporation of the organisms into the agar plate itself may influence results (Irish et al., 2008). 

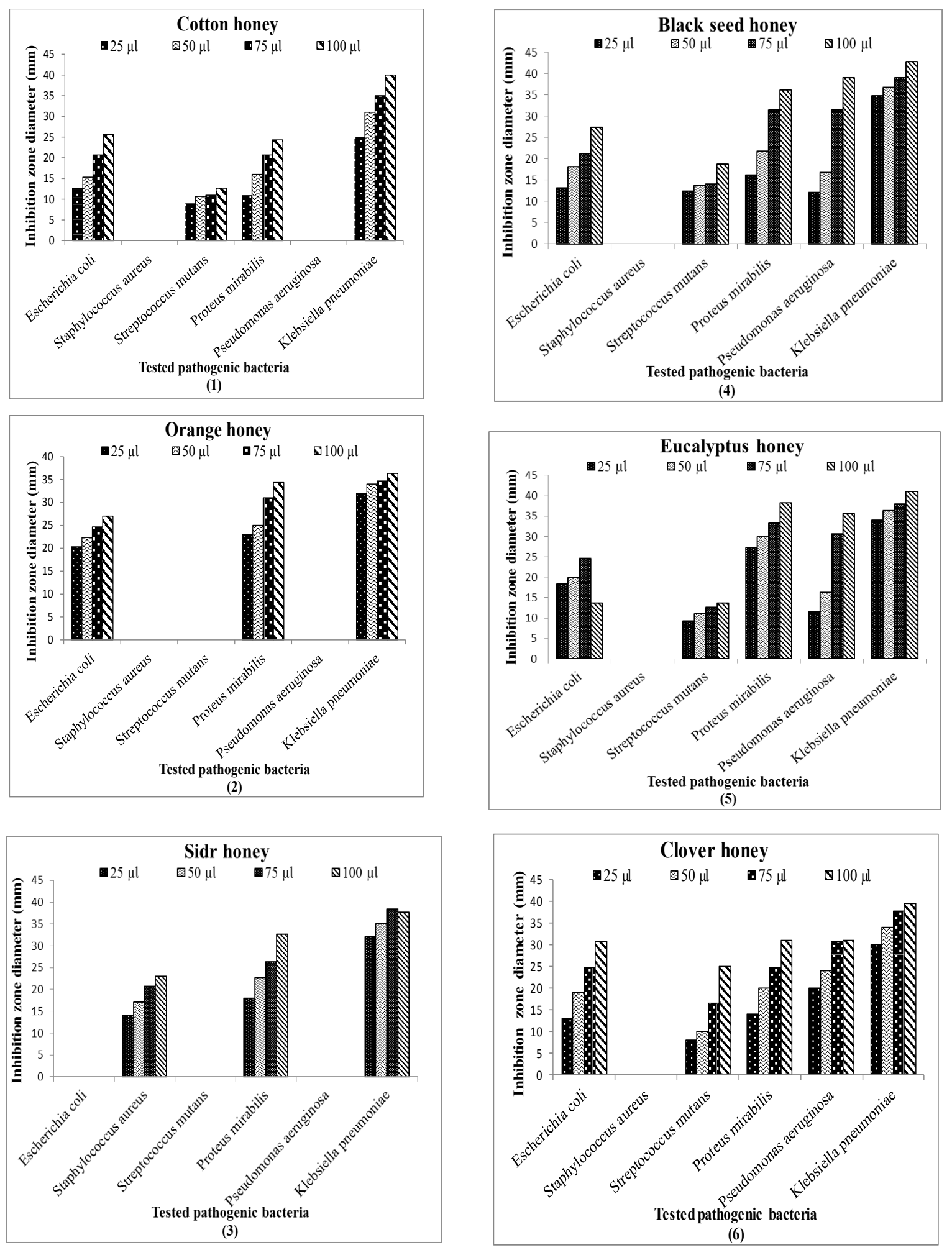

Fig. 1-6.The inhibition zone of different types of honey against various pathogenic microorganisms by well diffusion method. 
Minimum inhibitory concentration (MIC)

The MIC of the different types of honey against the pathogenic bacteria $S$. aureus, $S$. mutans, $P$. aeruginosa, E. coli, P. mirabilis, K. pneumonia is shown in Table 4. It was found that E. coli, $P$. mirabilis and $K$. pneumonia were affected by all types of honey compared with $P$. aeruginosa and $S$. mutans. While $S$. aureus showed high resistance for all honey types except for 100\% Sidr honey only, and this was contradicted by AlvarezSuarez et al. (2012) who reported that $S$. aureus is more sensitive to the action of honey than $P$. aeruginosa. At $25 \%$ concentration, Black seed and Eucalyptus honey had an effect on E. coli and $K$. pneumonia, while Clover honey had an effect on $P$. aeruginosa and $P$. mirabilis. In some studies, resistant and sensitive $P$. aeruginosa was resistant to Sidr honey (Alaa et al., 2015).

TABLE 4. Minimum inhibitory concentration (MIC) of different types of honey against the most susceptible bacteria. method.

\begin{tabular}{|c|c|c|c|c|c|c|c|}
\hline Tested pathogenic bacteria & Cotton & & Orange & Sidr & Black seed & Eucalyptus & Clover \\
\hline Staphylococcus aureus & - & - & 100 & - & - & & - \\
\hline Streptococcus mutans & 50 & - & - & 50 & 50 & & 50 \\
\hline Escherichia coli & 50 & 50 & - & 25 & 25 & & 50 \\
\hline Proteus Mirabilis & 50 & 50 & 50 & 50 & 50 & & 25 \\
\hline Klebsiella pneumoniae & 50 & 50 & 50 & 25 & 25 & & 50 \\
\hline
\end{tabular}

Many researchers investigated the role of the non-peroxide activity as part of the antimicrobial properties of honeys in ripe honeys, in which only a small amount of peroxide, is not sufficient for bacterial growth inhibition. And though it was found that the antibacterial activity of honeys was related to the polyphenols found therein. Nonperoxide compounds could mostly be related to the antibacterial effect which was by the studied honey samples, because the samples with the highest phenolic contents revealed the smallest MICs against the tested bacterial strains (Sousa et al., 2016).

\section{Conclusion}

The antioxidant and antimicrobial properties of locally produced honeys in Egypt make them highly added valuable products. The differences between honey samples in terms of antibacterial and antioxidant activity could be attributed to the natural variations in floral sources of nectar and the different locations. Honey has potential to play a role in providing antioxidants in a highly palatable form against reactive oxygen species causing most chronic diseases such as cancer, coronary and neurological degeneration. Moreover, the results revealed that the antibacterial effect of different types of honey is type and concentration dependent.

\section{References}

Adenekan, M.O., Amusa, N.A., Lawal, A.O. and Okpeze, V.E. (2010) Physicochemical and microbial properties of honey samples obtained from Ibadan. Journal of Microbiology and Antimicrobials, 2, 100-104.

Alaa, A.M., Saad, B.A., El Sayed, M.A., Elie, B., Soad, K.A. and Steve, H. (2015) Antimicrobial activities of Saudi honey against $P$ seudomonas aeruginosa. Saudi Journal of Biological Sciences, 22, 521-525.

Alvarez-Suarez, J.M., Giampieri, F., Damiani, E., Astolfi, P., Fattorini, D., Regoli, F., Quiles, J.L. and Battino, M. (2012) Radical-scavenging activity, protective effect against lipid peroxidation and mineral contents of monofloral Cuban honeys. Plant Foods for Human Nutrition, 67, 31-38.

Bertoncelj, J., Doberšek, U., Jamnik, M. and Golob, T. (2007) Evaluation of the phenolic content, antioxidant activity and colour of Slovenian honey. Food Chemistry, 105, 822-828.

Bueno-Costa, F.M., Zambiazi, R.C., Bohmer, B.W., Chaves, F.C., Padilha da Silva, W., Zanusso, J.T. and Dutra, I. (2016) Antibacterial and antioxidant activity of honeys from the state of Rio Grande do Sul, Brazil. Food Science and Technology, 65, 333-340.

Chang, C., Yang, M. and Wen, H. (2002) Estimation of total flavonoid content in propolis by two complementary colorimetric methods. Journal of Food and Drug Analysis, 10, 178-182. 
Chen, C., Campbell, L.T., Blair, S.E. and Carter, D.A. (2012) The effect of standard heat and filtration processing procedures on antimicrobial activity and hydrogen peroxide levels in honey. Frontiers in Microbiology, 265, 1-7.

Chua, L.S., Rahaman, N.L., Adnan, N.A. and Tan, T.E. (2013) Antioxidant activity of three honey samples in relation with their biochemical components. Journal of Analytical Methods in Chemistry, 2013;2013:313798. doi: 10.1155/2013/313798.

Egan, H., Ronald, K. and Ronald, S. (1987)"Pearson's Chemical Analysis of Food", $8^{\text {th }}$ ed. Longman Group, London.

Ferreira, I.C., Aires, E., Barreira, J.C. and Estevinho, L.M. (2009) Antioxidant activity of Portuguese honey samples: Different contributions of the entire honey and phenolic extract. Food Chemistry, 114, 1438-1443.

Hazra, B., Santana, B. and Nripendranath, M. (2008) Antioxidant and free radicals scavenging activity of Spondias pinnata. Biomedical Central, 8, 63.

Irish, M., Lawlor, B.A., O'Mara, S.M. and Coen, R.F. (2008) Assessment of behavioural markers of autonoetic consciousness during episodic autobiographical memory retrieval: A preliminary analysis. Behavioural Neurology, 19, 3-6.

Jain, P.K. and Agrawal, R.K. (2008) Antioxidant and free radical scavenging properties of developed mono- and polyherbal formulations. Asian Journal of Experimental Sciences, 22, 213-220.

Khalil, M.I., Sulaiman, S.A. and Gan, S.H. (2010) High 5 hydroxymethylfurfural concentrations are found in Malaysian honey samples stored for more than one year. Food and Chemical Toxicology, 48, 23882392.

Koleva, I., van Beek, T., Linssen, J., de Groot, A. and Evstatieva, L. (2002) Screening of plant extracts for antioxidant activity: A comparative study on three testing methods. Phytochemical Analysis, 13, 8-17.

Lachman, J., Hejtmánková, A., Sýkora, J., Karban, J., Orsák, M. and Rygerová, B. (2010) Contents of major phenolic and flavonoid antioxidants in selected Czech honey. Czech Journal of Food Sciences, 285, 412-426.

Liberato, M.C., Morais, S.M., Siqueira, S.M., Menezes, J.E., Ramos, D.N., Machado, L.K. and Magalhaes, I.L. (2011) Phenolic content and antioxidant and antiacetyl cholinesterase properties of honeys from different floral origins. Journal of Medicinal Food, 14, 658-663.
Malika, N., Mohamed, F. and Chakib, E. (2005) Microbiological and physico-chemical properties of Moroccan honey. International Journal of Agriculture and Biology, 7, 773-776.

Meda, A., Lamien, C.E., Romito, M., Millogo, J. and Nacoulma, O.G. (2005) Determination of the total phenolic, flavonoid and proline contents in Burkina Fasan honey, as well as their radical scavenging activity. Food Chemistry, 91, 571-577.

Mehrotra, S., Srivastava, A.K. and Nandi, S.P. (2010) Comparative antimicrobial activities of Neem, Amla, Aloe, Assam Tea and Clove extracts against Vibrio cholerae, Staphylococcus aureus and Pseudomonas aeruginosa. J. Med. Plants. Res. 4, 2393-2398.

Melissa, A.M., Olga,, I. and Randy, W.W. (2004) Growth inhibition of food borne pathogens and food spoilage organisms by select raw honeys. International Journal of Food and Microbiology, 97, 1-8.

Mohammed, M. Chua, Y.A., Pasupuleti, V.R., Mohammad, N.I., Amirah, B.M., Azlan A.S. and Siew, H.G. (2014) Identification of phenolic acids and flavonoids in monofloral honey from Bangladesh by high performance liquid chromatography: Determination of Antioxidant Capacity. Bio.Med. Research. International, 11, 1-11.

Natalia, R.B., Marlon, H.A., Isabela, F.J., Fabricio, M.A., Eduardo, P.A., Elena, B.L., Michelle, F.M. and Daniela, B.O. (2014) Nitric oxide production, inhibitory, antioxidant and antimycobacterial activities of the fruits extract and flavonoid content of Schinus terebinthifolius. The. Brazilian. Journal. of Pharmacognosy, 24, 644-650.

Patton, T., Barrett, J., Brennan, J. and Moran, N. (2006) Use of a spectrophotometric bioassay for determination of microbial sensitivity to manuka honey. Journal, of Microbiological. Methods, 64, 84-95.

Pontis, J.A., Alves da Costa, L.A., Reis da Silva, S.A. and Flach, A. (2014) Color, phenolic and flavonoid content, and antioxidant activity of honey from Roraima. Brazilian Food Science and Technology (Campinas), 34, 69-73.

Rabeta, M.S. and Nur Faraniza, R. (2013) Total phenolic content and ferric reducing antioxidant power of the leaves and fruits of Garcinia atrovirdis and Cynometra cauliflora. International. Food. Research. Journal, 20, 1691-1696.

Radwan, S.S., El-Essawy, A.A. and Sarhan, M.M. (1984) Experimental evidence for the occurrence in honey of specific substances active against microorganisms. Centralbl Microbiology, 139, 2249-2255. 
Rai, M., Yadav. A., Gade, A., (2009) Silver nanoparticles as a new generation of antimicrobials. Biotechnology. Advances, 27, 76-83.

Ramos, O.Y., Salomon, V., Libonatti, C., Cepeda, R., Maldonado, L. and Basualdo, M. (2018) Effect of botanical and physicochemical composition of Argentinean honeys on the inhibitory action against food pathogens. Food. Science. and Technology, 87, 457-463.

Rao, P.V., Krishnan, K.T., Salleh, N. and Gan, S.H. (2016) Biological and therapeutic effects of honey produced by honey bees and stingless bees: A comparative review. Revista, Brasileira. de Farmacognosia, 26, 657-664.

Rice-Evans, C.A., Miller, N.J., Bolwell, P.G., Bramley, P.M. and Pridham, J.B. (1995) The relative activities of plant-derived polyphenolic flavonoid. Free Radical Research, 22, 375-383.

Ruagg, M. and Blanc, B. (1981) The water activity of honey and related sugar solution. Lebensm-WISS U-Technology, 14, 1-6.

Salonen, A., Virjamo, V., Tammela, P., Fauch., L. and Tiitto, R.J. (2017) Screening bioactivity and bioactive constituents of Nordic unifloral honeys. Food Chemistry, 237, 214-224.

Samie, A., Mduluza, T., Sabeta, C.T., Njayou, M., Bessong, P.O. and Obi, C.L. (2005) Detection and differentiation of Entamoeba histolytica and Entamoeba dispar from clinical samples by PCR and enzyme-linked immunosorbent assay. Journal of Tropical Microbiology and Biotechnology, 1, 3-9.

Singleton, V.L., Orthofer, R. and Lamuela-Raventos, R.M. (1999) Analysis of total phenols and other oxidation substrates and antioxidants by means of Foline Ciocalteu reagent. Methods in Enzymology, 299, 152-178.

Sousa, J.M., Leite, de Souza, E., Marques, G., Meireles, B., Cordeiro, A.T., Gullón, B., Pintado, M.M. and Magnani, M (2016) Polyphenolic profile and antioxidant and antibacterial activities of monofloral honeys produced by Meliponini in the Brazilian semiarid region. Food Research International, 84, 61-68.

Sutharsingh, R., Kavimani, S., Jayakar, B., Uvarani, M. and Thangatirupathi, A. (2011) Quantitative phytochemical estimation and antioxidant studies on aerial parts of Naravelia zeylanica DC. International Journal of Pharmaceutical Sciences and Research, 2, 52-56.

Taormina, P.J., Niemira, B.A. and Bauchat, L.R. (2001) Inhibitory activity of honey against foodborne pathogens as influenced by the presence of hydrogen peroxide and level of antioxidant power. International. Journal. of Food. Microbiology, 69, 217-225.

Vorwohl, G (1964) The measurement of the electrical conductivity of the honey and the use of the measuring values for the stenotic diagnosis and the detection of adulteration with honey. Journal. of Bee. Research, 7, 37-47.

William, H. (1980) "Official Methods of Analysis of the Association of Official Analytical Chemists", 13 $3^{\text {th }}$ ed. Association of Official Analytical Chemists, Washington, DC, 520p. 


\section{النشاطات المضادة للبكتيريا و للأكسدة لأنواع مختلفة من العسل المصرى المنتج محليا}

علياء محمود البرعى1، غادة أمين يوسف1، دعاء أحمد الغريب23، و مى محفوظ عبد التواب1

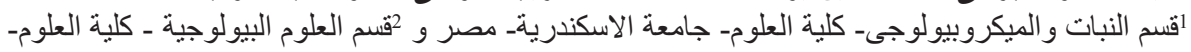

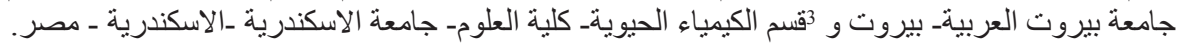

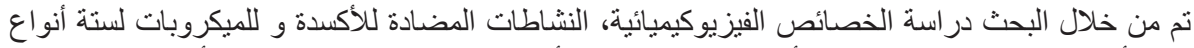

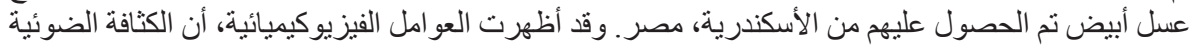

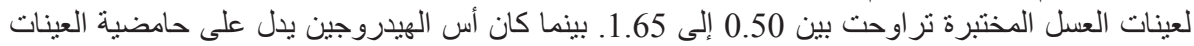

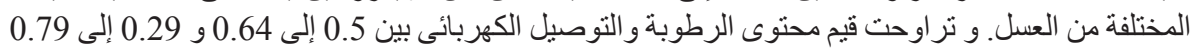

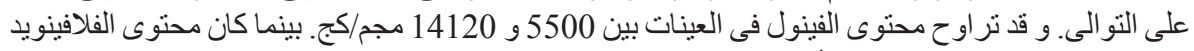

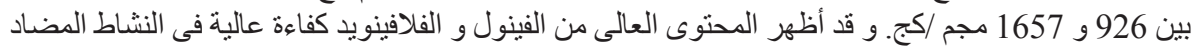

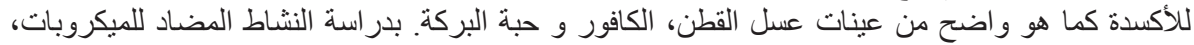

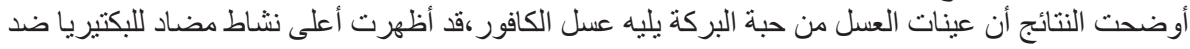

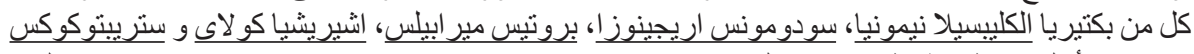

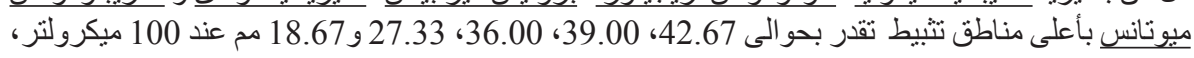

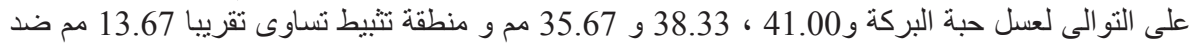

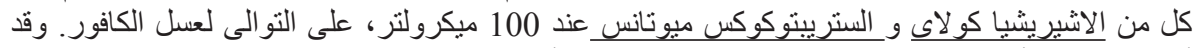

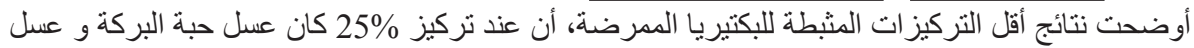

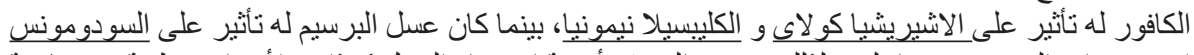

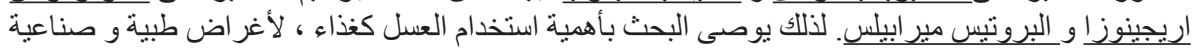

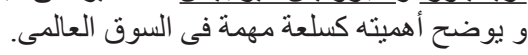

